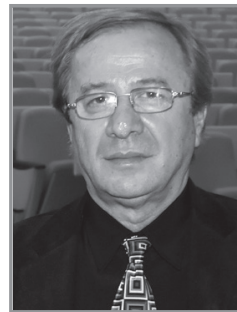

Мирко МИЛЕТИЋ

Факултет друштвених наука

Београд

\title{
АНТИЧКО И
}

\section{ХРИШЋАНСКО НАСЛЕЪЕ У КОМУНИКОЛОГИЈИ}

Апстракт: У раду се указује да најранији теоријски концепти о комуницирању потичу из реторичких учења у античкој Грчкој и Риму, а затим се могу пронаћи у средњовековној хришћанској, патристичкој и схоластичкој егзегези.

Говор и разговор су, као реторичке теме, били у средишту пажње грчких филозофа класичног периода, касније и у Риму, а недоумица да ли добар говорник говори истину или добро говори представља и данас, не само реторички, него и подстицајан комуниколошки проблем. Хроничари истраживања комуницирања примећују да је интелекстуалистичко-садржајни правац у античкој реторици извршио и врши утицај на европске комуникологе, сличан оном који реторско-формалистички остварује на главну струју америчких истраживача комуницирања. У средњем веку хришћанство и реторика постале су нераздвојне у проповедништву и молитвама, а тежиште поменуте дилеме премештено је из области етике и логике у сферу догме. У теолошким радовима развијен је читав низ молитвених и проповедничких правила за интраперсонално комуницирање са метафизичким бићима, интерперсонално комуницирање верника и комуницирање свештеника са публиком верујућих људи.

Рад се завршава закључком да је у савремености мало теорија о комуницирању које, макар индиректно, не узимају у обзир реторичке постулате настале у античко и средњевековно доба, „предисторијском” периоду савременог интердисциплинарног истраживања и промишљања људског комуницирања.

Кључне речи: АНТИЧКА ЦИВИЛИЗАЦИЈА, ХРИШЋАНСТВО, РЕТОРИКА, СЕМИОТИКА, ХЕРМЕНЕУТИКА, КОМУНИЦИРАҢЕ, КОМУНИКАЦИОНА СИТУАЦИЈА, КОМУНИКАЦИОНИ ЧИН, КОМУНИКОЛОГИЈА. 
У евроцентричној интерпретацији настанка и развоја не само тзв. западне цивилазације, него и цивилизације уопште, уобичајено је да се корени савремене филозофије, науке, уметности и свеколиког духовног стваралаштва траже и налазе у античким друштвима, најпре у старој Грчкој, посебно у класичном и хеленистичком периоду, а потом и у античком Риму, све до коначне поделе ове велике империје на Источно и Западно царство. То, наравно, никако не значи да и друге древне цивилизације (египатска, кинеска, индијска, асирска, вавилонска, јудејска, персијска...) нису дале значајне доприносе целини човековог духовног стваралаштва, али чињеница је да савремени свет почива, нарочито када је о филозофији и науци реч, на сазнајним и вредносним постулатима античке, грчко-римске и хришћанске цивилизације.

Утолико је разумљиво што се и корени најранијих теоријских концептуализација неких од бројних аспеката комуницирања препознају у мишљењима и учењима античких филозофа. Тим пре, ако се има у виду историјска очигледност да су, најпре, бројни хришћански схоластици у средњем веку, а потом и ренесансни уметници и мислиоци, као и просветитељи на почетку новог века, били под извесним, мањим или већим, утицајем античког филозофског и теоријског наслеђа. Оно се може препознати и у значајном броју теорија $и$ модела² комуницарања у савремености - од краја XIX столећа до данас.

\section{Античка реторика и комуницирање}

Стара Грчка је општи појам за скуп врло специфичних социјалних заједница, грчких градова-држава, односно полиса, који су настајали, трајали и нестајали током 'аксијалног доба' од 800. до 200. године пре нове ере, према Јасперсу

1Научна теорија се може разумети као епистемолошки заокружени систем чињенично, логички и вредносно аргументованих знања, тј. доказаних и доказивих хипотеза, о одређеном аспекту или аспектима стварности, који је условљен друштвено-историјским контекстом и идејнофилозофским оквиром у којима настаје, једнако као и предеметом истраживања и промишљања и научним методом, чија је примена неизбежна претпоставка профилисања сваке теорије. Следствено, теорије о кумуницирању су заокружени системи логички, чињенично и вредносно аргументованих знања, тј. доказаних и доказивих хипотеза, о одређеном аспекту или аспектима комуницирања.

2Модел (лат. modulus: мера, стандард; образац, план, опис) је физичка (умањена или увећана), иконичка (схеме) и/или вербална (искази/обрасци/формуле) симулација одређеног аспекта стварности (материјалног објекта, система идеја, теорије...). Могуће је успоставити мноштво критеријума за препознавање различитих модела, али је са становишта разумевања модела комуницирања најприхватљивија класификација која садржи две врсте научних модела сразмерне и аналогне. „У оба случаја модел врши селекцију једног скупа пертинентних обележја предмета који одржава или приказује (...). Сразмерни модел настоји да репродукује форму оригиналног предмета, док аналогни модели настоје да репродукују само апстрактне структуре или системе релација оригиналног предмета" (Eko, 2001:224). Утолико су сви модели комуницирања аналогни модели и могу представљати полазиште, део или илустрацију одређене, одређених или, чак, свих теорија о комуницирању (тзв. општи модели комуницирања). 


\section{Мирко МИЛЕТИЋ}

Факултет друштвених наука

(Karl Jaspers) периоду преломних дешавања у настајању основа цивилизације савременог човека (Jaspers, 1953). Поред осталог, њихова специфичност изаржавала се у територијалној скучености, последично, и реалтивно малом броју становника. Простирали су се на пар хиљада квадратних километара и имали од пет до десет хиљада житеља. Разлог за такво организовање класичногантичког полиса је уверење савременика, подједнако државника и филозофа, да би територијално ширење полиса и драстично повећање броја становника у градовима-државама довело у питање њихову функционалност у свим областима друштвеног живота. Платон (Пגа́ $\tau \omega \nu)$ је сматрао да полис треба да се шири само до границе до које може да допре људски глас, а идеалан број домаћинстава

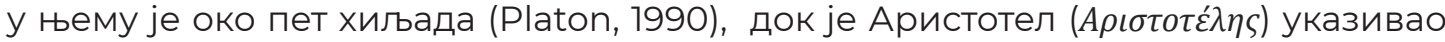
да је граница развоја града-државе територија која може да буде обухваћена погледом, тврдећи да полис од сто хиљада људи то више није, јер се њиме не може владати (Aristotel, 1984).

„Грцима је био незамислив политички живот заједнице у којој се људи не познају, јер како изабрати неког човека, поверити му јавну функцију ако га не познајете? Како да одлучује скупштина, тај 'колективни разум полиса' ако се на Агори не могу сви окупити? Како да се одлучује ако разговор није могућ, разговор 'свих који се тиче', а тицало се свих. Зато је Грк морао познавати полис, он му је био стално пред очима." (Mićunović, 1987: 128)

У полису - на трговима, скупштинама и тржницама, у судским расправама и храмовима - људске интеракције оствариване су интерперсоналним и комуницирањем са различитим публикама. Стога је логично што је комуницирање, у античкој Грчкој, промишљано искључиво као реторички проблем.

„Бављење људском комуникацијом у класичном раздобљу заправо је бављење реториком." (Reardon, 1998: 28)

Међу грчким реторичарима није било неслагања о телеолошком исходу разговара са себи равним и говора себи равним, дакле житељима полиса који су имали право приступа и говорења у јавној сфери - циљ разговора/расправе или говора/беседе је убеђивање саговорника и/или слушалаца у исправност јавно израженог мишљења. Проблем је, међутим, био етички оквир за постизање жељеног степена персуазије, тј. однос између садржаја и форме који се артикулисао питањем да ли је важније шта се говори од тога како се говори и обратно, при чему се сама вештина говорења (како се говори) подразумевала и учила. „Ако желиш да дете живи са боговима, подучавај га филозофији, а ако желиш да живи са људима, подучавај га реторици." (Сократов ученик Антистен; према Аврамовић, 2008) Давање предности садржају или форми говорења профилисало је два приступа у старогрчкој реторици: реторско-формалистич- 
ки и интелекстуалистичко-садржајни (Petrović, 1975), односно формално-естетички и логичко-етички (Bogdanić, 1996).

Историјски посматрано, реторика се, и као вештина расправљања и беседништва и као филозофско промишљање те вештине, најпре (од средине $\checkmark$ века п.н.е.) развијала у оквиру реторско-формалистичког, односно формално-естетичког приступа, у коме је предност давана вештини расправљања и беседништва, насупрот истинитости реторичког исказа. Један од разлога могао би бити агонистичкиㄹ дух који је владао у друштвеном животу античких Грка, још из од времена митско-поетског поимања света. То показује и Хомерова „Илијада” у којој се Тројански рат објашњава вољом богиње неслоге, раздора и свађе Ериде4. Такав дух није афирмисан само у борбама и атлетским такмичењима, него и у духовним, тј. уметничким, филозофским и беседничким надметањима.

„Надметање краљева доводи до рата, и победа се опет слави у бојним играма, а победнике у њима величају и песници и пластичари, који се опет надмећу једни с другима. И тако непрестано све даље, све духовније, један агон изазива други. Борбе у оружју живе и даље у сећању, и придружују се у уметничкој фантазији, митолошкој, епској и пластичној. Пластика ствара борбене групе и поезија разбија своје лирско јединство и развија се у надметање фигура у драми, којим се опет песници надмећу једни са другима и пред судијама. И као мртви јунаци боре се њихови мртви песници - као Ајант и Одисеј боре се Хомер и Хесиод, па Есхил и Еурипид, против других песника и беседника, а ови се опет између себе надмећу у сјајним беседама и говорима на суду и постају учитељи парламентарне и јуристичке вештине у расправљању. А са беседницима и песницима, опет се надмећу филозофи (...)." (Joёl, 1927: 105-106).

Најистакнутији заступници овог реторичког правца били су софисти, а њи-

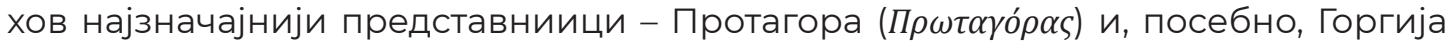

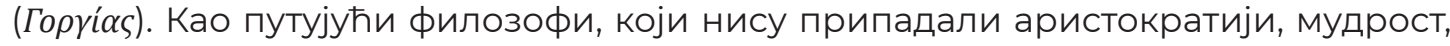
знање и реторички наук су наплаћивали. Били су, наиме, веома популарни, тако да се често, у појединим градовима, славио њихов долазак, а млади богати људи плаћали су слушање њихових говора и изучавање беседничке вештине. Отуд, можда, и инсистирање на вештини расправљања и беседништва, а не на веродостојности реторичког исказа. Горгија је сматрао да врлина (грч. arete) није суштина реторичког исказа, већ способност убеђивања, коришћењем одговарјаућих речи. Тврдио је да добро изабране речи могу имати божанску моћ и ефекте као примењена физичка сила, поредећи њихово дејство на душу као дејство лекова на организам.

3 Грч. agon: борба, утакмица, такмичење.

4 „Пој, богињо, љутост..." (Хомер, 2004) 
„Према Горгији, реч (је) велика моћница 'која је наговорила душу, присилила је (ону) коју је наговорила и да се покори (ономе) што се говори и да одобри (оно) што се ради'. Моћ речи може да изазове покоравање и одобравање." (Tadić, 1994: 12)

Веровао је да се њима могу контролисати емоције, инсистирајући на поетској прозодији приликом њиховог изговарања, као и коришћењу стилистичких 'украса' који појачавају утицај на публику. Већина доксографа сматра да је овакав Горгијин приступ реторици проистекао из његовог гносеолошког и етичког нихилзма, уверења да је објективну истину не само немогуће утврдитити, него и саопштити, те да је истина увек индивидуална, а широко прихваћена истина само последица вештине убеђивања. Јер, како је изложио у изгубљеном делу „О природи и непостојању”, чији су ферагменти сачувани у делу Секста Емпи-

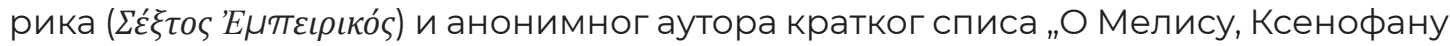
и Горгији”, за Горгију: ништа не постоји; чак и ако нешто постоји, ништа се не може знати о томе; чак и ако нешто може да се зна о томе, знање о томе не може саопштити другима; чак и ако се може саопштити, не може се истозначно разумети. (према Bizzell \& Herzberg, 2001: 22-25)

Други, интелектуалистичко-садржајни или логичко-етички приступ реторици заснован је у Платоновој критици софистичке реторике, коју је окарактерисао као умећа ласкања, испразне еристике и изопачивања стварности, чија је делотворност могућа захваљујући људској глупости. Платон је тврдио да реторика није ни наука ни уметност, него само умеће које служи да се превари публика.

„Та вештина и спретност у говору, која отуда потиче, добија се као дар ако неко заузврат да награду у новцу. Нашој држави таква вештина уопште не треба, било да је реч о правој вештини или само о некој извежбаности која није права вештина." (Platon, 1990: 226)

Износећи овако омаловажавајуће мишљење о реторици, био је мотивисан софистичким поједностављивањем њеног телеолошког смисла, али то не значи да је одустао од могућности развијања филозофске реторике, утемељене у дијалектици, а усмерене према спознаји истине.

„Нужан услов за оно што треба да буде лепо и ваљано речено (је) у томе да се душа онога који говори разумева у истину оних ствари о којима жели да говори" (Platon, 1979: 259).

Платон заступа мишљење да је реторика потребна и пожељна, али само уколико је утемељена на утврђеним правилима. Та правила су дијалектичка, јер је срж дијалектике постављање правих питања и проналажење истинитих одговора. Према Платону, 
„реторика (..) постаје метод за филозофа и његове ученике, ослобођене од конвенционалних веровања и свих световних терета, у трагању и евентуалном достизању трансцендентално апсолутне истине" (Bizzell \& Herzberg, 2001: 29),

што је сушта супротност софостичком утилитаризму у разумевању и практиковању реторике искључиво као 'корисне вештине'.

Индиректна критика ова два дијаметрално супротна приступа садржана је у

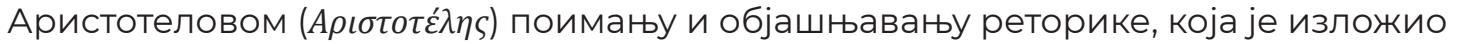
у делима „Реторика” и „Никомахова етика”. У њима, посебно у првом, Аристотел нуди свестрану анализу реторике као феномена, анализарајући све елементе који га структурирају.

„С једне стране, она је повезана са Аристотеловом логиком, етиком и политиком, а с друге стране представља практични приручник за јавне говорнике..." (Oates, 1963: 355)

Аристотел је, наиме, „Реторику” написао првенствено као филозофско дело, истичући у први план принципе на којима почива, али тако да се, практичним саветима које садржи, може користитити и као дидактичко штиво.

Слично софистима и свом учитељу Платону (у формалном, не и телеолошком и етичком смислу), Аристотел реторику најпре доводи у везу са појмом techne (вештина, умеће, уметност), али је, истовремено, повезује и са појмом dynnmis (способност). Добар говорник не може да развије вештину беседништва без способности да је примени у пракси, те

„да се њезин основни задатак не састоји у уверавању, него у изналажењу уверљивог у сваком датом случају" (Aristotel, 1987: 13/1355 б),

из чега проистиче и његово одређења реторике:

„Нека реторика буде способност теоријског изналажења уверљивог у сваком датом случају" (исто: 1356 а).

Појмови techne и dynnmis, стога, су оквир за филозофску концептуализацију реторичке тријаде у објашњавању свих детерминанти који утичу на ефекте јавног говора: ethos, pathos и logos.

За Аристотела је ethos скуп не свих, већ само морално-интелектуалних особина говорника које слушаоци узимају као својствене његовој личности и, на основу претходног расуђивања о њима, вреднујући говорника, вреднују и го- 
вор. Уколико је ethos говорника са становишта слушалаца неупитан, утолико је за њих уверљивији, будући да је уверљивост говора последица ауторитета говорника, који је израз његовог каректера, тј. морално-интелектуалних особина које се огледају у врлини (arete), као честитости (epieikeia) и добронамерности (eunoia), али и разборитости (phronesis). Врлина подразумева разборитост, а разборитост утиче на pathos који не сме да изађе из њених оквира. Али pathos, схваћен у ужем смислу као скуп примењених реторичких средстава којима се појачава уверљивост говора, мора укључити и својства аудиторијума, укључујући и способност слушалаца да препознају ethos говорника. Зависно од те способности, која истовремено са средствима реторичког уверавања обликује pathos, артикулише ce logos, као смисаоно одржив садржај говора који, логички разумљивим скупом аргумената и противаргумената, утиче на његову уврељивост и последице које изазива у адиторијуму.

Према томе, за разлику од софиста који су инсистирали на питању како говорити у зависности од тога коме се говори и од Платона који је проблематизовао питање шта се говори, наглашавајући значај онога ко говори, Аристотел је реторику разумео као умеће и вештину уверавања која подједнако зависи од говорника, слушаоца/слушалаца и самог говора, наглашавајући значај не само онога како се говори и шта се говори, него и ко говори коме говори, где и када говори и како говори. Тиме је, гледано из данашње перспективе, скицирао све елементе говорне (комуникационе) ситуације и говорног (комуникационог) чина, који представљају епистемолошку основу за промишљање људског комуницирања и у савремености у свим облицима комуникационе праксе.

Њима су се у потоњих неколико векова бавили и сви истакнутији римски реторичари, међу којима се издвајају Цицерон и Квинтилијан. Обојица, међутим, не надилазе грчке филозофе, већ их допуњују сопственим виђењима онога што је Аристител назвао techne и dynnmis у јавном говору, истићући у први план питања ко говори и како говори, тј. особине доброг говорника и уверљивих говора.

Марко Тулије Цицерон (Marcus Tullius Cicero), и сам велики и чувени говорник, у делима Orator („Говорник”) и De oratore („О говорнику”), указујући да је „говорништво сложенија појава него што то људи обично замишљају” (према Beker, 1997: 60), доброг говорника одређује као мудрог и човека великог знања, који је познавалац теме, систематично је, јасно и привлачно излаже, комбинујући те квалитете са личном достојанственошћу. Систематичност, јасност и привлачност у беседништву зависи од од различитих публика којима се обраћа, па зато мора бити кадар да говор казује једноставним, средњим и узвишеним стилом (према Kennedy, 1994: 140).

Марко Фабије Квинтилијан (Marcus Fabius Quintilianus), који је својим обимним дванаестокњижним делом De institutio oratoria (у српском преводу - „Образовање говорника") засновао реторику и као теоријску дисциплину у Римском царству, сматрао је да само „честит и ваљан човјек може бити (добар - М. М.) говорник" (Kvintilijan, 1985: 490). За њега је такав говорник био управо Цицерон јер, 
пише, „не видим да је и у једному дијелу његове политичке каријере недостајала добронамјерност уистину ваљанога грађанина" (исто: 493). Квинтилијан реторику пореди са уметношћу - ars bene dicendi, говорника са уметником, а говор са уметничким делом. Преузимајући од Цицерона поделу стилова на једноставан (genus subtile), умерен (genus medium) и узвишен (genus grande), наглашава да публика одређује говорников стил, али сваки од ових стилова подразумева да

„Оно што смо у глави саставили и није толико важно колико начин на који то из себе дајемо”, јер „ниједан доказ који говорник наводи није сам по себи толико чврст да неће на снази изгубити уколико не буде потпомогнут увејрљивим гласом говорника. Сва ће осјећања неизбјежно спласнути и ослабјети ако не буду потпомогнута гласом, изразом лица и читавим држањем тијела". Стога је моћ добре беседе увек у изазваним осећањима, будући да се у њима „огледа сва снага говорништва". (исто: 494)

\section{Комуницирање у хришћанској теологији}

У средњем веку, у оквиру хришћанске теологије, религија и реторика постале су нераздвојне у проповедништву и молитвама, а тежиште дилеме античких мислилаца о садржају и форми говора и разговора премештено је из области етике и логике у сферу догме. Бог је истина, а добар исказ је богоугодан исказ - својеврсни је теолошки кредо разрешења проблема садржаја и форме у хришћанској реторици.

„О уској повезаности кршћанске теологије с реториком свједоче и саме повијесне чињенице. Наиме, ако се изузме жидовство, кршћанство на религијском подручју античкога свијета представља прву религију која је у својим богослужнима чинима садржавала и читање светих текстова, односно Светога писма, те након тога и тумачење у облику проповиједи. То је представљало значајну новину у односу на дотадашњу религијску праксу, која је углавном познавала култове приношења жртава у тишини. А будући да је и у вријеме настајања и ранога развоја кршћанства реторика била високо вреднована, готово да није могла бити заобиђена у настојању нове религије да се што квалитетније усмено тумачи и преноси еванђеље." (Džinić, 2013: 93)

Тако се реторика полако преображавала у свој хришћански пандан - омилитику или хомилетику, тј. црквено проповедништво. Најважније правило је да се у црквеним проповедима и у молитвама мора показати потпуна оданост Богу и бескрајна скрушеност. У теолошким радовима развијен је читав низ проповедничких и молитвених правила за интраперсонално комуницирање са Богом, комуницирање свештеника са религиозном публиком, али и интерперсонално комуницирање верника. 
Међу првим хришћанским мислиоцима који се бавио хришћанским беседништвом био је Аурелије Августин (Aurelius Augustinus), који је постулате античке реторике успешно спојио са хришћанском догматиком, инсистирајући да једно од главних начела античке реторике - vir bonus dicendi peritus („добар човек вешт у говору"), мора у хришћанској омилитици незбежно подразумевати говорника који је најпре - praedicator verbi Dei („проповедник речи Божје”). Таквим приступом Августин у говорну/комуникациону ситуацију, поред говорника и слушаоца/слушалаца, укључује Бога на кога су, истовремено и једнозначно, упућени и говорник/проповедник и слушалац/слушаоци. Стога се Аугустин, својим виђењем морала и карактера говорника, разликује од античких мислилаца и реторичара.

„Лични живот говорника - његов хришћански допринос, уједначеност између онога што говори и ради - има већи уверавајући утицај него говорничке вештине и елоквенција." (према Kennedy, 1994: 269)

Наравно, он је свестан да вештина проповедања не сме бити занемарена, али само под условом да је проповедник понизан пред Богом и храбар да у свакој прилици саопштава истину која не постоји изван „Светог писма”.

Идеје о хришћанској реторици Августин је изложио у четири књиге De doctrina christiana („Хришћанска доктрина”) у којима се, такође, пионирски бавио семиотичким претпоставкама и хеременеутичким аспектима комунициpaњa (Augustine, 1995).

Тако, када је о семиотици реч, нуди два одређења знака. Прво: „Знаци су ствари које се користе да означе нешто. (...signa, res...quae ad significandum aliquid adhhibentur)”; и друго: „Знак је ствар која узрокује да мислимо на нешто изнад утиска коју ствар по себи изазива у чулима... (Signum est enim res praeter speciem, quam ingerit sesibus, aliud aliquid ex se faciens in cogitationem uenirem...)" (према Darrell, 1969: 11).

Али, „мислити нешто изнад утиска коју ствар по себи изазива у чулума” није могуће изван 'доктрине о четири смисла', коју је Августин утврдио у оквиру патристичке егзегезе, одговарајући на питање како се може (и сме) тумачити „Свето писмо”.

„Неке речи у том тексту имају дослован смисао (денотирају) и лако су разумљиве. Места која су у Светом писму нејасна, треба тумачити симболички, каже он. Тако се, у том тексту, осим денотативног могу пронаћи још алегоријски, морални и анагогијски (тајни, доступан само људима прожетим Светим Духом, потпуно посвећеним Богу - М.М.) смисао. Ван њих нема (и не сме да буде других смислова, према поставкама Августинове теолошке конвенције о међусобном одмосу знакова и означеног у Библији." (Радојковић и Ђорђевић, 2005: 176). 
'Доктрином о четири смисла' Августин је отворио један од најсложенијих херменеутичких проблема у разумевању и објашњавању комуницирања, који се односи тумачење садржаја људских интеракција и питања од кога и од чега зависи значење порука које се саопштавају и примају у сваком комуникационом чину.

Оно што је у патристици на почетку средњег века утемљено, у схоластици је, до краја средњовековља, заокружено у радовима бројних хришћанских схоластичара, међу којима је, свакако, најзначајнији Тома Аквински (Tommaso d'Aquino). Схоластичари полазе од религијског постулата да је права и једина истина дата у „Светом писму”, те је задатак реторике да ту истину докаже и објасни. Користећи и логику и дијалектику, дакле филозофију, али не да би се критиковала света истина, већ да би била одбрањена од јеретика, јер Philosophia ancilla theologiae est („Филозофија је слушкиња теологије.”).

Аквински је у књизи написаној између 1265. и 1274. године Summa Theologica („Зборник теологије”), која је намењена теолошком подучавању почетника, формулисао седам питања - он их назива околностима - на која треба дати убедљиве и уверљиве реторичке одговоре, који бране истину „Светог писма”. Та питања су: quis (ко), quid (шта), ubi (где), quibus auxiliis (чиме), cur (зашто), quomodo (како) и quando (када)? (Mary, 2000). Њиховим постављањем међу првима је, ако не и први, оивичио елементе сваке комуникационе ситуације, који су много векова касније, највероватније индиректно, утицали на Харолда Ласвела (Harold Lasswell) да постави познату формулу 5W, тj. „Who (says), what, (in) what channel, (to) whom, (with) what effect"/,ко (каже), шта, којим каналом, коме, (са) каквим ефектом" (Lasswell, 1948: 37), која се односи на истраживање најважнијих аспеката комуницирања.

\section{Закључак}

Прве целовите и заокружене теорије о комуницирању настале су крајем XIX и почетком XX столећа и од тада до данас има их више од стотину. Почев од биологистичко-механицистичке ес-ер теорије до савремених које се, углавном, односе на радикално преобликовање комуникационе праксе у новом мултимедијском, унимедијском и метамедијском окружењу.

„Узимајући у обзир идејна полазишта могуће је разликовати марксистичке, прагматистичке, феноменолошке, функционалистичке, структуралистичке, неомарксистичке, неофункционалистичке, постструктуралистичке и постмодернистичке теорије о комуницирању. Из угла филозофског приступа разликују се торије које се односе на онтолошке (шта истраживати), епистемолошке (како истраживати) и аксиолошке (зашто истраживати) проблеме у разумевању комуницирања. 
Полазећи од ширине предметног захватања у истраживање комуницирања, могу се препознати опште теорије о комуницирању, као свепрожимајућем природном и друштвеном феномену; теорије средњег домета, које се истовремено односе на одређене субјекте, контекст, садржаје, посреднике, ефекте и последице комуницирања; и теорије ниског обима, у којима се истражује и постулира само један аспект одређеног облика комуницирања. Све оне могу имати монодисциплинарни (семиологија, лингвистика, антропологија, психологија, социологија) и интердисциплинарни (комуникологија, културологија, кибернетика) научни, као и метанаучни идентитет.

Са методолошког становишта могуће је говорити о теоријама које се заснивају на примени квалитативних и квантитативних метода истраживања комуницирања. Њихова примена омогућава разликовање критичко-хуманистичких и позитивистичко-емпиристичких теорија о комуницирању." (Милетић и Милетић, 2021: 362-363)

Мало је, међутим, теорија о комуницирању које, макар индиректно, не узимају у обзир реторичке постулате настале у античко и средњевековно доба, „предисторијском” периоду савременог интердисциплинарног истраживања и промишљања људског комуницирања. Ако је основно питање на које комуникологија, баш као интердисциплинарна наука о комуницирању, мора увек изнова да одговара - како људи комуницирају, онда је незаобилазно полазиште у таквом хеуристичком напору препознавање промена у структури комуникиационе ситуације и моментима комуникационих чинова у савременој комуникационој пракси, који су најпре профилисани у учењима класичних античкихи хришћанских мислилаца.

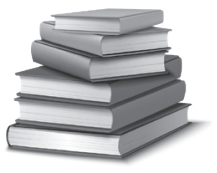

\section{ЛИТЕРАТУРА}

1. Augustine (1995): De doctrina Christiana; Oxford: Clarendon Press.

2. Аврамовић Сима (2008): Retorike techne - вештина беседништва и јавни наступ; Београд: Службени гласник и Правни факултет.

3. Aristotel (1984): Politika; Beograd: BICZ.

4. Aristotel (1987): Retorika; Beograd: Nezavisna izdanja Slobodana Mašića.

5. Aristotel (2003): Nikomahova etika; Novi Sad: Budućnost.

6. Beker Miroslav (1997): Kratka povijest antičke retorike; Zagreb: Artrezor.

7. Bizzell Patricia \& Herzberg Bruce (2001): The Rhetorical Tradition; Boston/New York: Bedford/St. Martin's. 
8. Bogdanić Aleksandar (1996): Komunikologija: vodeća paradigma; Beograd: Čigoja. Darrell Jackson (1969):The Theory of Signs in St. Augustine's De doctrina christiana; Charllote: Queens College.

9. Eko Umberto (2001): Granice tumečenja; Beograd: Paideia.

10. Jaspers Karl (1953): The Origin and Goal of History; New Heaven, CT: Yale University Press.

11. Joël Karl (1921): Geschichte der antiken Philosophie; Tübingen.

12. Kvintilijan Flavije Marko (1985): Obrazovanje govornika (odabrane strane); Sarajevo: Veselin Masleša.

13. Kennedy George (1994): A New History of Classical Rhetoric; New Jesrey: Princeton University.

14. Lasswell, Harold (1948). Bryson, L., ed. The Structure and Function of Communication in Society. The Communication of Ideas. New York: Institute for Religious and Social Studies. p. 37.

15. Mary T. Clark, ed. (2000): An Aquinas Reader: Selections from the Writings of Thomas Aquinas. Fordham: University Press.

16. Милетић Мирко и Милетић Невена (2021): Комуниколошки лексикон, треће измењено и допуњено издање; Београд: Јасен.

17. Mićunović Dragoljub (1987): „Polis - između zajednice i države”, Filozofija i društvo, l; Beograd: Institut za filozofiju i društvenu teoriju.

18. Oates Whitney (1963): Aristotle and the Problem of Value; New Jersey: Princeton University Press.

19. Petrović Sreten (1975): Retorika; Niš: Gradina.

20. Platon (1968): Protagora - Gorgija; Beograd: Kultura.

21. Platon (1969): Država; Beograd: Kultura.

22. Platon (1979): Ijon. Gozba. Fedar; Beograd: Kultura.

23. Platon (1990): Zakoni; Beograd: BICZ.

24. Radojković Miroljub i Đorđević Toma (2005): Osnove komunikologije. Beograd: FPN i Čigoja.

25. Reardon K. Kathleen (1998): Interpersonalna komunikacija-Gdje se misli susreću; Zagreb: Alinea.

26. Tadić Ljubomir (1994): „Retorika i demokratija”, Filozofija i društvo, V; Beograd: Institut za filozofiju i društvenu teoriju.

27. Хомер (2004): Илијада; Нови Сад: Школска књига.

28. Džinić Ivo (2013): „Retorika i homiletika. Neke teološke rasprave o odnosu dviju disciplina", Bogoslovska smotra, Vol 83, No 1; Zagreb: Katolički bogoslovni fakultet Sveučilišta u Zagrebu. 


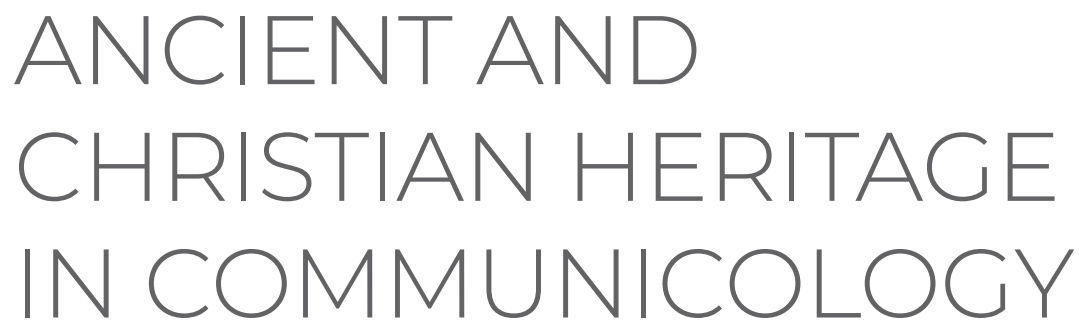

Abstract: The paper points out that the earliest theoretical concepts of communication originated from rhetorical teachings in ancient Greece and Rome, and then can be found in medieval Christian, patristic and scholastic exegesis.

Speech and conversation, as rhetorical topics, were in the center of attention of Greek philosophers of the classical period, and later in Rome, and the doubt whether a good speaker speaks the truth or speaks well is still not only a rhetorical, but also a stimulating communication problem. The chroniclers of communication research notice that the intellectual-content direction in ancient rhetoric has exerted the influence on European communicologists, similar to the one that rhetoricalformalistic direction exerts on the mainstream of American communication researchers. In the Middle Ages, Christianity and rhetoric became inseparable in preaching and prayer, and the focus of the mentioned dilemma was shifted from the field of ethics and logic to the sphere of dogma. In theological works, a whole series of prayer and preaching rules has been developed for intrapersonal communication with metaphysical beings, interpersonal communication of believers and communication of priests with the audience of believers.

The paper concludes that there are few theories of communication in modern times that, at least indirectly, do not take into account rhetorical postulates created in ancient and medieval times, the „prehistoric” period of modern interdisciplinary research and reflection on human communication.

Keywords: ANCIENT CIVILIZATION, CHRISTIANITY, RHETORIC, SEMIOTICS, HERMENEUTICS, COMMUNICATION, COMMUNICATION SITUATION, COMMUNICATION ACT, COMMUNICOLOGY. 